\title{
Jana ENGELBRECHTOVÁ
}

ORCID: 0000-0001-7526-8202

Univerzita Palackého v Olomouci

\section{Wilken ENGELBRECHT}

ORCID: 0000-0002-9058-8199

Univerzita Palackého v Olomouci / Katolicki Uniwersytet Lubelski Jana Pawła II

\section{Een unicum in Europa. Hugo de Groot en zijn Jodenreglement ${ }^{*}$}

\begin{abstract}
The article discusses the Jodenreglement (Jewish regulations) of Hugo Grotius (1615) and the circumstances under which this treatise was written. After a brief overview of the development of the concept of "tolerance", a short survey of the Jewish presence in the Netherlands is given. The article then discusses the reasons for drafting the treatise, the life of Hugo Grotius and the text itself which resulted in the de facto tolerance of Jews in Amsterdam.
\end{abstract}

Keywords: tolerance, Jews, Holland, Hugo Grotius, Jewish regulations, Amsterdam.

\section{Het begrip tolerantie}

Bij de heropening van de gerestaureerde Grote Synagoge te Amsterdam in 2004 stelde burgemeester Job Cohen met een verwijzing naar het Jodenreglement van de zeventiende-eeuwse rechtsgeleerde Hugo de Groot dat Amsterdam "een teken van tolerantie was dat lange tijd als voorbeeld gold voor de rest van Europa". We halen hier een substantieel deel van deze redevoering aan (Cohen):

Toen de allereerste joden rond 1600 naar Amsterdam kwamen, was er sprake van een samenloop van omstandigheden, die gunstig uitwerkte voor de vestiging van de joden. [...] Joden

* Dit artikel is het resultaat van ondersteuning in het project Rozvojový projekt M $\check{S} M T \check{C} R$ pro rok 2016 - podpora zahraničnich mobilit akademických pracovníků FF UP (Ontwikkelingsproject ministerie van onderwijs van Tsjechië voor 2016 - ondersteuning van buitenlandse mobiliteit van academici van de FF UP). 
waren anders, zij waren leden van de Joodse Natie, geen christenen. In het begin van de $17 \mathrm{e}$ eeuw ontstond daarom in Holland de behoefte om de positie van de joden nader te definiëren. Moeten we joden toelaten? Zo ja, op basis van een numerus clausus? Mogen joden zich overal vestigen in de stad, of alleen in bepaalde wijken (zoals in andere steden van Europa het geval was)? Hoe moeten joden zich tegenover christenen, en vooral christenvrouwen gedragen? Mogen joden hun godsdienst belijden in het openbaar en is dat niet ten nadele van de dominante protestantse godsdienst? Dat waren aan het begin van de 17e eeuw de vragen. De Staten van Holland vonden dat er een algemeen reglement moest komen dat deze vragen voor alle steden van Holland eenduidig zou beantwoorden. Zij gaven Adriaan Paauw en Hugo de Groot de opdracht om zo'n reglement te ontwerpen. Dat deden ze, ieder voor zich en de Remonstrantie nopende de ordre dije in de landen van Hollandt ende Westvrieslandt dijent gestelt op de Joden uit $1619^{1}$ van Hugo de Groot is voor ons behouden gebleven - maar tot een algemeen reglement is men door politieke twisten niet gekomen. De steden moesten het zelf maar bepalen.

Dit beeld van Amsterdam als "door de eeuwen heen tolerante stad" wordt vaak uitgedragen. De praktijk was, zoals o.a. zowel de bekende historicus Jonathan I. Israel (1997) als Joke Spaans (2004) hebben getoond, wat weerbarstiger. In deze bijdrage bekijken we hoe Hugo de Groot, bekend geworden als grondlegger van het internationale recht, zijn reglement had bedoeld, welke omstandigheden tot dit reglement hadden geleid en hoe het uitwerkte. ${ }^{2}$

Het begrip 'tolerantie' is afgeleid van het Latijnse tolerare dat oorspronkelijk 'verdragen' of 'ondersteunen' betekent (Lewis \& Short 1958: 1876). De vijfde-eeuwse encyclopedist Isidorus van Sevilla (ca. 570-636) vormde van dit werkwoord in zijn Sententiae 37.2-4 een nieuw begrip tolerantia, dat hij als een van de zeven deugden noemt en wel als tegenpool van ira, de onbeheerste woede. Tolerantie is voor hem het geduldig verdragen van ongewenste zaken. De eerste Nederlandse vertaling van het begrip tolerantia is van Jan van Ruusbroec in zijn Van zeven trappen in den graed der gheesteleker minne IV, 3e rivier. In deze vierde trap, de nederigheid (de hoogste van het werkende leven), zijn de begrippen 'tribulatiën' en 'dooeghen' centrale elementen. Het laatste woord is een rechtstreekse vertaling van tolerantia en de lexicale voorouder van het moderne gedogen. Hij omschrijft dit als "leven in verduldegheit".

Tolerantie was in de middeleeuwen dus een deugd: geduldig verdragen van afwijkende zaken. De eerste stap naar onze moderne definitie in de zin van het dulden van afwijkende 'meningen' kwam met het ontstaan van de lutherse kerk in 1524, waarbij de kerk werd gereduceerd tot de gemeenschap der gelovigen, zonder feitelijke politieke macht. Dit leidde bij de Unie van Utrecht (1579) tot het standpunt dat geloof een privékwestie is (Bakhuizen van den Brink 1960: 164).

${ }^{1}$ De Remonstrantie is uit 1615 , het uiteindelijke besluit van de Staten is wel van 1619 , zie hierna.

2 Toen de eerste versie van dit artikel op basis van de in 2018 gehouden lezing al was geschreven, kwam de nieuwe becommentarieerde facsimile-uitgave uit, opgesteld door David Kromhout en Adri Offenberg, Hugo Grotius's Remonstrantie of 1615 (Leiden: Brill 2019). De bevindingen uit deze nieuwe uitgave zijn in deze bijdrage verwerkt. 
De praktijk was minder eenvoudig. Toen de Nederduits Gereformeerde Kerk na 1579 als 'publieke kerk' semi-staatskerk was geworden, deden de dominees hun uiterste best om afwijkende theologische geluiden te onderdrukken, culminerend in de veroordeling van de in gereformeerde ogen 'rekkelijke' remonstranten op de Synode van Dordrecht in 1619 en hun verbanning (Israel 1997: 9-13).

Dat het in Nederland nooit tot een strikt calvinistische staat in contraremonstrantse zin is gekomen, is het gevolg van verschillende zaken - ten eerste hing feitelijk de meerderheid van de bevolking een ander geloof aan dan het gereformeerde, ten tweede vond de heersende elite van Hollandse steden als Amsterdam, Leiden en Rotterdam de handel veel belangrijker dan scherpe geloofsijver, en ten derde drukte de nieuwe stadhouder Frederik Hendrik na 1625 een politiek van wederzijdse tolerantie door (Poelhekke 1978: 166). Gevluchte remonstranten konden na 1625 terugkeren, mits zij verder niet voor problemen zouden zorgen, in veroverde, merendeels katholieke steden mocht de bevolking katholiek blijven, mits de belangrijkste kerk aan de gereformeerden werd overgegeven en de magistraat minimaal formeel de 'publieke kerk' ging aanhangen. Frederik Hendrik was de eerste Oranje die openlijk de joden tolereerde: op 22 mei 1642 bezocht hij de Portugese synode Talmoed Tora in Amsterdam (Zwarts 1928: 238; Van Eijnatten \& Van Lieburg 2006: 186). Betekende dit dat de stadhouder 'rekkelijk' was op het stuk van religie, een houding waarvan strenge calvinisten hem beschuldigden? Allerminst: het bleef bij gedogen, al weigerde de prins om aan politieke druk gehoor te geven en bijv. zijn wekelijkse kerkgang te verleggen van de Hofkapel op het Binnenhof, waar veel ex-remonstranten ter kerke bleven gaan, naar de Kloosterkerk, waar de echte contraremonstranten heen gingen (Poelhekke 1978: 172-175).

Zo ontstond er een maatschappij met een 'publieke kerk' waar men lid van moest zijn om functies te kunnen hebben, ${ }^{3}$ maar die nimmer staatskerk is geworden, zoals dit de regel was in andere landen (Spaans 2004: 75). Tegelijkertijd kon zo goed als iedereen zijn geloof belijden, ook van religies die officieel verboden waren als de katholieke. Omdat in de Republiek een effectieve censuur ontbrak, oefende zij grote aantrekkingskracht uit op mensen die zich in hun eigen land niet vrij konden uiten. Een van hen was John Locke (1632-1704) die van 1683 tot aan de Glorious Revolution van 1688 in Nederland verbleef en hier het grootste deel van zijn tractaat An Essay Concerning Human Understanding schreef. Zowel dit werk als zijn Epistola de tolerantia werden na zijn terugkeer in Engeland in het gevolg van stadhouder-koning Willem III gedrukt in resp. 1690 en 1689. Dit tweede werk, deels gebaseerd op ideeën van Dirk Volckertsz. Coornhert (1522-1590), stond aan de basis van het moderne tolerantie-idee. Locke stelt:

${ }^{3}$ In de praktijk werd vooral na 1625 met deze eis de hand gelicht. Zo kon de remonstrant Laurens Reael bewindhebber van de VOC en vice-admiraal van Amsterdam worden, was de katholiek Jan Vos directeur van de Amsterdamse schouwburg, en waren joodse kooplui invloedrijke beleggers in de Amsterdamse Wisselbank. 
Ecclesiastical Assemblies, and Sermons, are justified by daily experience, and public allowance. [...] Thus if Solemn Assemblies, Observations of Festivals, publick Worship, be permitted to any one sort of Professors, all these things ought to be permitted to the Presbyterians, Independents, Anabaptists, Arminians, Quakers, and others, with the same Liberty. Nay, if we may openly speak the Truth, and as becomes one Man to another, neither Pagan, nor Mahometan, nor Jew, ought to be excluded from the Civil Rights of the Commonwealth because of his Religion. The Gospel commands no such thing. [...] If we allow the Jews to have private Houses and Dwellings amongst us, Why should we not allow them to have Synagogues? Is their Doctrine more false, their Worship more abominable, or is the Civil Peace more endangered by their meeting in publick than in their private Houses? But if these things may be granted to Jews and Pagans, surely the condition of any Christians ought not to be worse than theirs in a Christian Commonwealth (Locke 1689: 53-54).

Dit is min of meer vergelijkbaar met wat Artikel 1 van de Nederlandse Grondwet uitdrukt:

Allen die zich in Nederland bevinden, worden in gelijke gevallen gelijk behandeld. Discriminatie wegens godsdienst, levensovertuiging, politieke gezindheid, ras, geslacht of op welke grond dan ook, is niet toegestaan.

\section{De joden in Nederland}

In de Nederlandse politiek wordt de laatste jaren veel over de 'joods-christelijke basis' van de Nederlandse samenleving gesproken. Hoe zat het eigenlijk met het samenleven van joden en Nederlanders? Om te beginnen is de aanwezigheid van joden in Nederland vanuit Europees gezichtspunt vrij recent. De eerste tastbare bewijzen dateren pas van rond 1255, toen de dochter van een rabbijn in Tienen werd begraven (Blom e.a. 1995: 21). Al spoedig doken ook de eerste antisemitische maatregelen op: Hendrik III van Brabant vond dat er 'teveel' joden in zijn hertogdom waren en bepaalde in zijn testament van 1261 dat alleen zij die het woekeren zouden opgeven, in Brabant mochten blijven. Zijn weduwe Aleydis leek dit geen goed idee -als gevolg van het verbod op rente door het Derde Concilie van Lateranen (1179) dat niet voor joden gold, waren zij praktisch de bankiers van de adel en de overheid geworden. Juist om die reden werden zij vaak beschermd door landsheer en kerkelijke overheid. Aleydis vroeg daarom de bekende kerkvader Thomas van Aquino (ca. 1225-1274) om raad. Deze stelde het eerste jodenreglement op, De regimine Judaeorum (Over het bestuur over de Joden, 1261), waarin hij de raad gaf om aan joden de uitoefening van hun beroep mogelijk te maken, maar hen herkenningstekens te laten dragen (Blom e.a. 1995: 21-22).

De Zwarte Dood van 1348 leidde tot hevige pogroms in heel Europa, waarop de Nederlanden geen uitzondering vormden. In 1349 en 1350 werden joden in Brabant, Gelre en het Oversticht massaal vermoord (Blom e.a. 1995: 25). Uiteindelijk werden alle joden tussen 1444 en 1488 uit heel Nederland verbannen. In deze periode was er dus absoluut geen sprake van tolerantie, maar liep Nederland 
qua antisemitisme in de pas met omringende gebieden. Via de handelsbanden met Portugal kwamen er na 1511 weer joden in de Nederlanden, waarbij Antwerpen, destijds de draaischijf van de lange-afstandshandel in Noordwest-Europa, hun belangrijkste vestigingsplaats werd (Blom e.a. 1995: 62).

Hoewel de katholieke landsheer Karel V meermalen de Portugese joodse en 'nieuw-christelijke' Marranen (gedoopte joden) uit Brabant verbande, achtte de Antwerpse magistraat hun aanwezigheid noodzakelijk voor de lange-afstandshandel. Aan het begin van de Opstand waren er rond 1570 dan ook 85 joodse en nieuw-christelijke families en 17 vrijgezellen, alles bij elkaar ongeveer 250 tot 300 mensen, aanwezig op de Antwerpse bevolking van ongeveer 40.000 zielen, nog geen procent. Omdat verschillende Italiaanse steden een soortgelijke politiek bedreven, kregen de 'Portugezen' een centrale rol in het internationale handelsnetwerk.

$\mathrm{Na}$ de herovering van Spanje op de Moren had koning Ferdinand II in 1492 alle Spaanse joden voor de keus gesteld tussen christen worden of weggaan. Velen lieten zich dopen, anderen gingen naar het tolerantere Portugal. Toen Filips II in 1578 ook koning van Portugal werd, werden hier de Spaanse anti-joodse wetten doorgevoerd. Dit zorgde voor een exodus van Portugese joden, o.a. naar Antwerpen. Na de inname van Antwerpen door de Spanjaarden in 1585, moesten zij verder vluchten. Ze gingen naar Amsterdam. In 1588 kregen "die van de Natie van Portugael" van de Staten-Generaal het recht om in de Nederlanden handel te drijven. In 1597 kocht Emanuel Rodriguez Vega, een nieuw-christen, het poorterrecht van Amsterdam, waar hij een zijdespinnerij begon. Hij was, zoals hij verklaarde, op de vlucht voor de verschrikkingen der wrede Inquisitie (Zwarts 1928: 156-157, 164-165). Een van zijn zakenpartners was de gelovige jood Abraham Jessurun de Spinoza, destijds gevestigd in Nantes als specerijenhandelaar, die zich na 1616 ook in Amsterdam vestigde en in 1622 administrator werd van het eerste joodse kerkhof Beth Haim in Ouderkerk aan de Amstel.

Hoewel de hervormer Johannes Calvijn zelf de Hebreeuwse bijbel positief waardeerde en nimmer tot jodenvervolging had opgeroepen, kwam de sterkste oppositie tegen de vestiging van joden in de Republiek van calvinistische zijde, uiteraard met een beroep op het Woord Gods - de joden waren immers 'de moordenaars van de Heer'. De directe aanleiding voor het Jodenreglement van Hugo de Groot was het samenleven van joden met christenen en dan met name de eventuele bekering van christenen tot de 'Israëlitische religie'.

\section{Kerkelijke protesten tegen de joden}

Uit de protocollen van de Amsterdamse Kerkenraad die door Jac. Zwarts voor zijn studie zijn geraadpleegd, blijkt dat er tussen 1590 en 1604 herhaaldelijke pogingen van binnengekomen joden waren om toestemming voor een synagoge te krijgen. De Alkmaarse vroedschap stond als eerste stad in de Republiek op 10 mei 1604 de 
geloofsbeleving van de joden toe (Zwarts 1928: 187; De Groot 1949: 38; Kromhout \& Offenberg 2019: 15). In Amsterdam slaagde de gereformeerde kerkenraad erin om het gebruik van een ruimte als synagoge lang te dwarsbomen. Een eerste aanvraag in 1608 werd onder druk van de kerkenraad door de burgemeesters afgewezen.

De eerste officiële synagoge, zij het volgens het beproefde schuilkerkmodel, werd door de burgemeesters van het remonstrantse Rotterdam op 14 augustus 1610 aan de joden toegestaan Zwarts 1928: 204-205; De Groot 1949: 45; Kromhout \& Offenberg 2019: 19). Deze Esnoga kwam bijeen op zolder van het huis van David Namias (ofwel João da Vega) en de begraafplaats Beis Hakkeworous ${ }^{4}$ aan de Jan van Loonslaan werd in 1613 voor 200 gulden door Gratias Rodriguez Vega gekocht

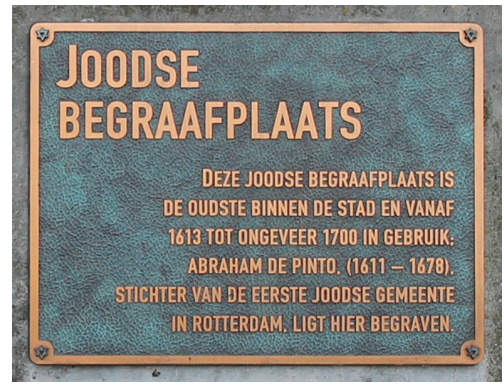

Afbeelding 1. Het bordje bij de Joods begraafplaats Beis Hakkeworous; foto's overgenomen van URL <https:// commons.wikimedia.org/wiki/File:Joodse_begraafplaats_ Jan_van_Loonslaan_1.jpg> (CC BY-SA 4.0)

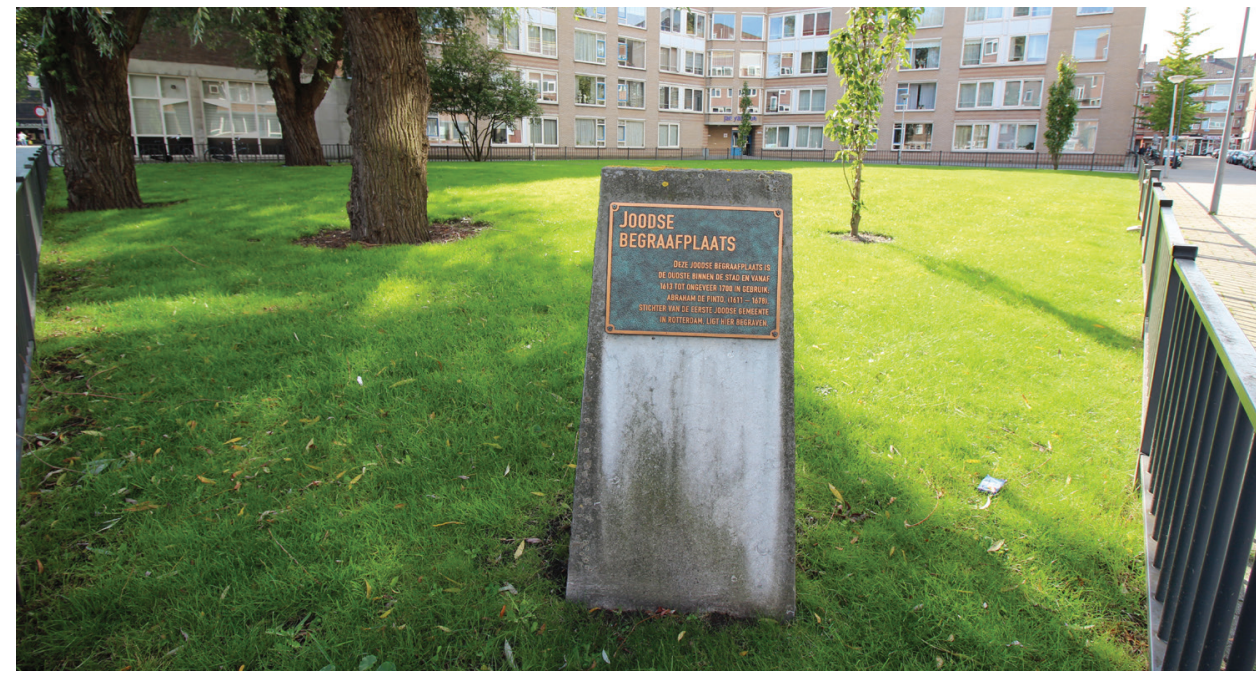

Afbeelding 2. De begraafplaats Beis Hakkeworous; foto's overgenomen van URL $<$ https://commons.wikimedia.org/wiki/File:Joodse_begraafplaats_Jan_van_Loonslaan_1.jpg > (CC BY-SA 4.0)

${ }^{4}$ Beis Hakkeworous is een Asjkenazische verbastering van het Hebreeuwse Beth ha-Kevoroth, het Huis der Begravenen (met dank aan Heidi Warncke van het Joods Cultureel Kwartier van Amsterdam voor de uitleg). 
en in gebruik genomen. Hier werden tot 1700 overleden Rotterdamse joden begraven (Droogendijk 1930) en nog altijd zijn er 16 zerken aanwezig (zie foto's). ${ }^{5}$

Niet onbelangrijk is dat 1613 juist het jaar is dat een jonge advocaat, Hugo de Groot, tot pensionaris van de stad Rotterdam werd benoemd, in welke functie hij de op 20 juli 1612 overleden Elias van Oldenbarnevelt (ca. 1557-1612) opvolgde.

In Amsterdam trad de joodse gemeente formeel als 'Portugese natie' op, maar bestond feitelijk uit twee gemeenten - Beth Jacob, gesticht rond 1597, en Neve Shalom, gesticht in 1612 (Zwarts 1928: 209). ${ }^{6}$ De wens van een echte gebedsruimte bleef bestaan, maar het was de Sefardim duidelijk dat dit op felle tegenstand van de calvinistische dominees zou stuiten. In 1612 werd daarom begonnen met de bouw van een synagoge aan de Houtkopersburgwal die formeel onderdeel was van een Casa de Nacion Portuguesa - een soort consulaat van de Portugese natie in Amsterdam. ${ }^{7}$ Dit voornemen leidde tot scherp protest van de kerkenraad, waarna de Amsterdamse vroedschap op 8 mei 1612 een afwijzende resolutie uitvaardigde (Kromhout \& Offenberg 2019: 21; Zwarts 1928: 215) concludeert dat de Amsterdamse vroedschap, anders dan de kerkenraad, geen moeite had met al eerder toegestane religieuze samenkomsten van de joden. Wél vreesde de vroedschap kennelijk dat een sterk Portugese kolonie als vijfde kolonne binnen Amsterdam kon fungeren - men was immers in oorlog met Spanje, en Portugal was een deel van het Spaanse rijk.

Als gevolg daarvan waren de 'Portugezen' nu gedwongen om zich openlijk als joodse gelovigen te bekennen. Voor de kerkenraad was de beer nu echt los. Bovendien vonden er elders in Europa en in de Republiek gebeurtenissen plaats die de hele 'joodse kwestie' urgent maakten. In Frankfurt am Main kwam het op 22 augustus 1614 tot rellen van de gilden onder leiding van de koekenbakker Vinzenz Fettmilch (ca. 1565-1616). Daarbij werd voor 170.000 toenmalige goudguldens schade aangericht en 's anderendaags werden alle joden uit Frankfurt verdreven. Dit schaadde de stedelijke economie aanzienlijk en Fettmilch werd in 1615 voor zijn leidende rol in deze opstand bestraft met vierendeling. ${ }^{8}$

${ }^{5}$ Zie $<$ https://www.joodserfgoedrotterdam.nl/begraafplaats-jan-van-loonslaan-beis-hakkeworous/>, laatst geraadpleegd op 5.03.2019.

${ }^{6}$ Kromhout \& Offenberg 2019: 18 (noot 29), zijn van mening dat er geen eenduidig bewijs is dat Beth Jacob al voor 1616 bestond.

7 Zwarts (1928: 213, noot) wijst op soortgelijke constructies in Antwerpen en Hamburg. Kromhout \& Offenberg (2019: 21) geven ten onrechte aan dat met de bouw op de Houtgracht was begonnen, waar een paar jaar later rond 1618 drie kleinere synagogen waren ontstaan en waar uiteindelijk in de jaren 1671-1675 ook de prachtige, nog steeds bestaande Portugese Synagoge werd gebouwd. Uit de door Zwarts (1928: 209/215, met bijlagen XVII en XVIII op pp. 260-264) blijkt dat het om twee verschillende plaatsen gaat die wel slechts een paar honderd meter van elkaar verwijderd waren.

${ }^{8}$ Drukker Michiel Colijn had in 1614 een vertaling gemaakt van een Duits verslag hiervan die als Nieuwe Tijdingh. Waerachtigh Bericht uyt de Stadt Franckfort aen de Mayn van t'gheen aldaer onder de Burgheren, Hantwercks-Ghesellen ... ende den Joden is toe-ghevallen, zodat de Amsterdammers dit gebeuren min of meer uit de eerste hand hadden (kopie aanwezig in de KB Den 
Vrijwel gelijktijdig kwam het in Hoorn tot het enige proces tegen joden ten tijde van de Republiek. Lokale joden zouden protestantse christenen bekeerd hebben tot hun religie. De schout Claesz Boelens arresteerde alle drie de bekeerlingen in september $1614^{9}$ en wilde hen naar de beste traditie van de inquisitie in een soort autodafe laten executeren. De magistraat voorkwam dit en vroeg advies bij de Staten van Holland en Westfriesland. Dezen deden op 9 april 1615 uitspraak en adviseerden om de bekeerlingen uit de stad te verbannen (Van der Haven 2018: 166). Het ging om twee mennonieten uit de omgeving van Emmerik, Abraham Abrahamszoon en Sara Thijsdochter die waarschijnlijk in de mennonietengemeente van Dantzig in aanraking waren gekomen met Poolse socinianen, ${ }^{10}$ en een voormalige gereformeerde ouderling, Jan Pieterszn. Cuyper. Het eerstgenoemde paar had in de periode 1585-1600 in Polen, Litouwen en Dantzig geleefd en had zich in 1607 bij de joodse gemeente van Amsterdam gevoegd. Wegens hun armoede waren ze in 1613 naar het plaatsje Grosthuizen bij Hoorn gegaan, waar zij eenden vingen die ze als koosjer vlees aan de plaatselijke joden verkochten. Daar hadden zij de ouderling ontmoet, die zich na discussies met hen ook tot het jodendom had bekeerd. Cuyper liet een van zijn zoons trouwen met de dochter van een zekere Jan Rijkcx, een schoenlapper en hoedenmaker die al eerder tot het jodendom bekeerd was. Deze was weer bekend met een Amsterdamse flessenmaker Pieter die kennelijk gelieerd was met een illegale joodse school in de ververijen van de Vloijenburgh. Dit bracht de kerkenraad weer in actie: ze besloten op 12 juni 1614 een klacht in te dienen bij de burgemeesters. De vroedschap legde de klacht naast zich neer (Zwarts 1928: 219 met bijlage XX op pp. 265-266) met bijlage XX op pp. 265-266).

\section{Het Jodenreglement}

Zowel de klachten en acties van de contraremonstrantse kerkenraad in Amsterdam, als het proces in Hoorn waarbij de remonstrantse predikant Johannes Wallesius was betrokken die zijn contraremonstrantse opponent ds. Dirck Chris-

Haag onder signatuur KW Pflt 2106). Zwarts (2019: 220) brengt dit gebeuren dat gematigdere leden van de Amsterdamse vroedschap zeer moet hebben geschokt, mede in verband met de opdracht tot opstellen van een ontwerp voor een jodenkeur.

9 De exacte datum is onbekend, maar het eerste verhoor door de schout vond plaats op 27 september 1614 (Van der Haven 2018: 117). Alexander van der Haven die een diepgaande studie naar dit al eerder bekende maar nooit goed onderzochte proces heeft gemaakt, heeft hiervoor het Westfries Archief bestudeerd, o.a. de Oudrechterlijke Archieven (bijlagen tot de schoutsrol 1550-1796, WfA 4497). Vergelijk ook De Groot (1949: 48-50) en Kromhout \& Offenberg (2019: 22).

10 Deze socinianen waren zogeheten anti-Trinitariërs die alleen God als goddelijke persoon erkennen. In Nederland stonden zij meestal als "Poolse Broeders" bekend. De mennonietengemeente van Dantzig had contacten met socinianen. 
tiaensz ervan had beschuldigd met zijn brute predestinatiepreken de ouderling tot afvalligheid te hebben gedreven, waren er de oorzaak van dat de Staten van Holland en Westfriesland besloten om een jodenreglement te laten opstellen (Kromhout \& Offenberg 2019: 22).

Omdat inmiddels de geschillen tussen remonstranten en contraremonstranten al flink begonnen op te lopen, werd de opdracht voor zo'n reglement op 4 maart 1615 gegeven aan twee ideologische opponenten - Adriaen Pauw (1585-1653), de contraremonstrantse pensionaris van Amsterdam, ${ }^{11}$ en Hugo de Groot (15831645), die als protégé van raadspensionaris Johan van Oldenbarnevelt net het jaar daarvoor diens overleden broer Elias als pensionaris van Rotterdam was opgevolgd (Kromhout \& Offenberg 2019: 20).

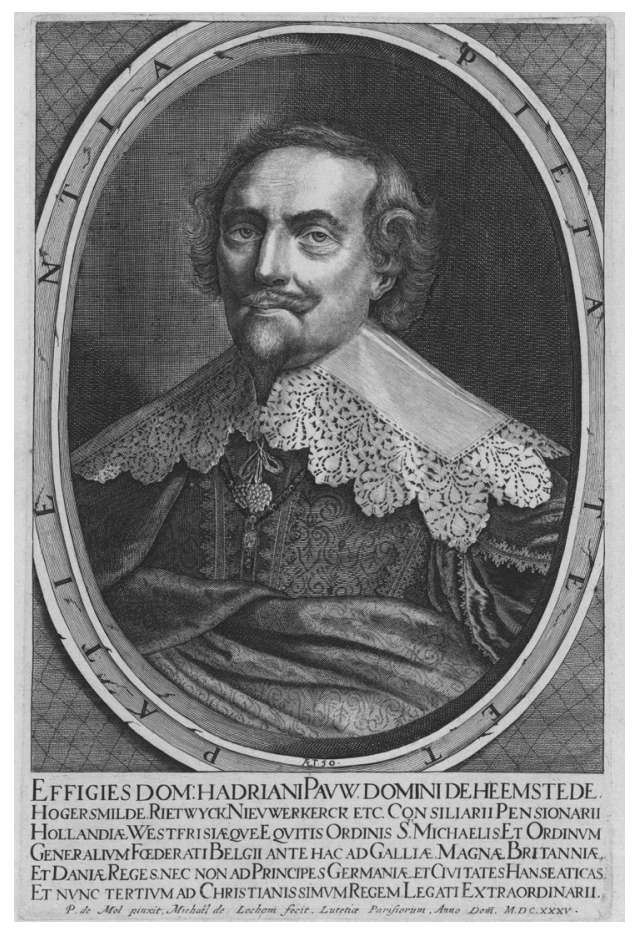

Afbeelding 3. Adriaen Pauw. Gravure Michiel van Lochom (1635); bron: Michiel van Lochom, gravure van het portret van Adriaen Pauw naar het schilderij van Peter van Mol, 1635. Rijksmuseum Amsterdam, signatuur RP-P-AO-1920-1624

11 Resolutie Staten van Holland, Nationaal Archief, inventarisnr. 49, p. 6 (tekst zie Kromhout \& Offenberg 2019: 22, noot 37). Zwarts (1928: 220) geeft in navolging van Prins als tweede persoon die de opdracht van de Staten kreeg Reinier Pauw (1564-1636), Adriaens vader. Sedert De Groot (1949: 51) wordt als tweede persoon Adriaen aangehouden, vgl. Kromhout \& Offenberg 2019: xi. 


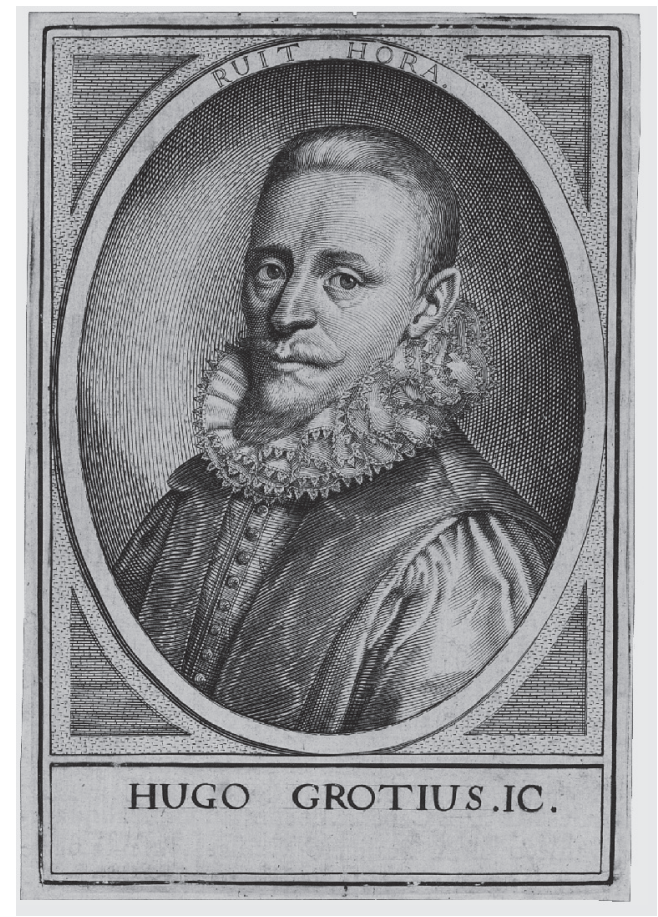

Afbeelding 4. Hugo de Groot. Gravure Andries Clouck (1613); bron: Andries Clouck, Hugo Grotius, in: Johannes Meursius, Illustris Academia Lug-dun-Batava. Lugdunum Batavorum: Andreas Cloucquius 1613, P iij. Allard Pierson, University of Amsterdam, OTM: Pr. K 102

Beiden hadden ervaring met 'de joodse kwestie'. Pauws vader Reinier was oprichter geweest van de Compagnie van Verre, één van de voorlopers van de VOC. Cornelis de Houtman (1565-1599), de zeeman die in opdracht van Petrus Plancius (1552-1622) kaarten had bemachtigd ${ }^{12}$ en in 1595/1596 de zogeheten Eerste Schipvaart naar Java had volbracht, was zijn familielid. De handel met 'Oost-Indië' was deels in handen van Marranen die dus feitelijk Pauws en Plancius' concurrenten waren. Plancius ijverde als dominee meermalen tegen de joden, waarbij hij geen verdachtmaking schuwde:

Den 4 Januario 1612. Ds. Plancius rapporteert, dat hij meede de heeren der admiraliteyt gesproocken heeft, belangende de Joden ende vernomende, datter een Jode Mendis de heere Sog-

12 Dit stelt Jac. Zwarts (1928: 198) op gezag van Prins. In het algemeen wordt aangenomen dat Plancius de kaarten, vervaardigd door Bartholomaeus de Lasso, verkregen had via Cornelis de Houtman die ze in 1592 of 1593 in Lissabon had gestolen of gekocht (Koeman 1985: 38-41 en de daar aangegeven literatuur). 
gaert heeft willen bereeden, dat maget Maria niet kan bewesen worden, eene maget geweest syn, noch oyck ut den nieuwen testamente, dat Maria ut den huijsse Davits geweest zy. Ds. Jacobus verclaert, dat hy wel eenighe dinghen vernomen heeft, maer noch nader begeert te ondersoucken (Zwarts 1928: 205).

Dat Plancius het nodig vond om dit bij de admiraliteit te melden, doet vermoeden dat dat zijn belang als hoofdaandeelhouder van de Compagnie van Verre minstens zo belangrijk was voor het protest als geloofsredenen. Verbanning van de joden uit Amsterdam of zelfs uit heel Holland zou het terrein voor zijn eigen compagnie vrijmaken.

Hugo de Groot had als kersverse pensionaris van Rotterdam te maken gekregen met de eerste officiële acceptatie van joodse erediensten aldaar. Het Rotterdamse reglement was uitdrukkelijk opgezet met als reden

tot vordering van de trafique ende negotiatie binnen deze stadt dienstich (te) vinden, de Cooplieden van de Portugeesche natie met eenige privelegien ende vrijheden te inviteeren, omme binnen de voorseide stede te coomen resideeren (Zwarts 1928: 205).

In dit licht moet ook de eis van het minimum van 50 families, na een jaar bijgesteld naar 30, worden gezien. Dit kwam overeen met het merendeel van de in Amsterdam aanwezige Marranen. Zelfs dit lagere aantal werd niet gehaald, waarop de magistraat het contract in september 1612 liet verlopen, zonder overigens de joden uit te wijzen. Er bleef dan ook stabiel een groep joodse kooplui in Rotterdam wonen. Kortom, ook De Groot had, als vertegenwoordiger van Rotterdam, financieel belang bij de 'joodse kwestie', maar dan precies omgekeerd aan dat van de Amsterdamse pensionaris Pauw.

\section{Hugo de Groot}

Hoewel Hugo de Groot onder zijn humanistennaam Grotius internationaal een bekende persoon is, herhalen we hier kort zijn levensfeiten. Hij werd 10 april 1583 te Delft geboren als zoon van het vroedschapslid en burgemeester Joan Cornets de Groot (1554-1640). De hoogbegaafde jongen begon op zijn elfde rechten te studeren in Leiden en sloot deze studie op zijn zestiende af bij de bekende universiteit van Orléans. In 1601 kreeg De Groot van de Staten van Holland en West-Friesland de opdracht voor een werk waarin de continuïteit van de noordelijke Nederlanden werd beschreven. De Groot maakte in dit boekje Liber de antiquitate reipublicae Batavicae (over de oudheid van de Nederlandse Republiek) gebruik van het populaire idee dat de Bataven de rechtstreekse voorouders van de Nederlanders zouden zijn. Het boekje werd nog in 1610 door De Groot in het Nederlands vertaald.

Deze combinatie van Latijnse en Nederlandse publicaties paste hij in veel werken toe. Met zijn De iure praedae (1604, Het recht op buit) en Mare liberum 
$(1609)^{13}$ verdedigde hij de belangen van de door Van Oldenbarnevelt in 1602 geïnitieerde Verenigde Oostindische Compagnie. Interessant is dat dit voor particuliere belangen geschreven werkje ten grondslag ligt aan het internationale zeerecht. Met zijn De iure belli ac pacis (1625, Over het recht van oorlog en vrede) maakte hij zich onsterfelijk.

Grotius was in 1607 advocaat-fiscaal van het Hof van Holland geworden, een functie vergelijkbaar met de moderne Hoofdofficier van Justitie. Zoals hierboven aangegeven kwam daar in 1614 de functie van pensionaris van de stad Rotterdam bij. Deze was hoofdadviseur in ambtelijke zaken. Als Hollands advocaat-fiscaal had Grotius de opdracht gekregen om een geschrift op te stellen, waarin hij juridisch moest onderbouwen dat de Staten van Holland en West-Friesland het recht hadden om de elkaar verbitterd verketterende remonstranten en contraremonstranten het zwijgen op te leggen. Met dit geschrift, de Ordinum Hollandiae ac Westfrisiae pietas vindicata (1613, De vroomheid der Staten van Holland en West-Friesland verdedigd) was Grotius ongewild partij in het debat geworden. De Staten namen in januari 1614 een resolutie aan, waarbij beide partijen werden gemaand in vrede te leven.

Dit had een averechts effect: de contraremonstrantse partij vond dat de Staten zich competenties op kerkelijk gebied aanmatigden die zij ontbeerden. Grotius was nu gebrandmerkt als remonstrantse partijganger, temeer omdat de stad Rotterdam, waar hij pensionaris was, een remonstrants bolwerk was (Nellen 2007: 175). In 1618 overspeelde Johan van Oldenbarnevelt zijn hand door als tegenwicht voor de aan stadhouder prins Maurits getrouwe reguliere troepen waardgelders aan te werven. Hiermee overtrad hij zijn competenties, een feit dat hem en Grotius die hem hierin steunde is aangewreven. Verder nam een meerderheid van de Staten-Generaal tegen de zin van de Staten van Holland het besluit om de religieuze problemen op een nationale synode op te lossen.

Op 29 augustus 1618 werden de landsadvocaat Van Oldenbarnevelt, Grotius en andere remonstrantse partijgangers op het Binnenhof gearresteerd. Protesten van de Staten van Holland, de stad Rotterdam en vele anderen hadden geen effect. Stadhouder prins Maurits verving overal remonstrantse stadsbesturen door contraremonstranten. $\mathrm{Na}$ een proces van negen maanden werd van Oldenbarnevelt op 12 mei ter dood veroordeeld en 's anderendaags op het Binnenhof onthoofd. Grotius en anderen werden op de navolgende dagen tot levenslange gevangenschap veroordeeld. Tot de rechters behoorde o.a. Adriaen Pauws vader Reinier. Inmiddels was op 13 november 1618 de nationale synode in Dordrecht begonnen, waar de remonstrantse partij na 136 zittingen op 24 april 1619 eveneens veroordeeld werd. Alle remonstrantse predikanten werden in de volgende maanden uit hun ambt ontzet. De meesten gingen in ballingschap.

13 In 1614 uitgekomen als Vrye zeevaert, ofte Bewijs van't recht dat de inghesetenen deser geunieerde landen toecomt over de Indische coop-handel. 
Hugo de Groot werd op 6 juni 1619 in het staatsslot Loevestein gevangen gezet. Hij mocht zijn vrouw Maria van Reigersberch en dochter Cornelia meenemen. Hij kreeg een redelijk luxueus appartement ter beschikking. Hoewel contact met de buitenwereld beperkt was, mocht de hoge gevangene wel wat omhanden hebben. In de gevangenis ontstonden enkele van zijn belangrijkste werken als de Inleiding tot de Hollandsche Rechtsgeleerdheid en het Bewys van den waren godsdienst. Na ruim een jaar werd ook het correspondentieverbod opgeheven. Voor het studiewerk waren er veel boeken nodig die steeds in een grote boekenkist werden aangevoerd. In zo'n kist ontsnapte Grotius op 22 maart 1622.

De rest van zijn leven bracht hij, op een korte periode in 1631 na toen veel remonstranten dankzij de nieuwe stadhouder Frederik Hendrik amnestie hadden gekregen, in ballingschap door. Eerst was hij gast van kardinaal Richelieu in Parijs, na 1634 was hij hier officieel gezant van koningin Christina van Zweden. In december 1644 werd hij teruggeroepen naar Zweden. Koningin Christina wilde Grotius tot haar hofbibliothecaris maken. Onderweg deed hij in mei 1645 kort zijn vaderland aan, waar hij vriendelijk onthaald werd en op 7 juni kwam hij in Zweden aan. Het aanbod om bibliothecaris te worden, sloeg Grotius af, omdat hij het Zweedse klimaat ongezond vond (Nellen 2007: 580-586). De Zweedse regering moest echter vanwege de oorlog bezuinigen op het aantal diplomaten en verleende hem daarom eervol ontslag met een fors pensioen ineens. Op weg terug naar Frankrijk kwam zijn schip naar Lübeck op 17 augustus in een storm in grote problemen, werd onbestuurbaar en spoelde in Achter-Pommeren op $80 \mathrm{~km}$ van Dantzig aan, honderden kilometers uit de koers. Grotius besloot om de $600 \mathrm{~km}$ vandaar naar Lübeck te paard af te leggen en bereikte een week later Rostock. Onderweg bleek hij een longontsteking te hebben opgelopen, waaraan hij op 28 augustus 1645 stierf. Zijn overschot werd op 3 oktober in de Nieuwe Kerk van Delft begraven.

\section{Het Jodenreglement}

Het manuscript van Hugo de Groots Remonstrantie nopende de ordre die in den landen van Hollandt ende Westvrieslandt dient gesteld op Joden is bewaard gebleven in de Livraria Montezinos, de in 1675 bij de bouw van de Portugese Synagoge van Amsterdam gestichte bibliotheek. Deze bibliotheek is sinds 1889 als Bibliotheek Ets Haim (Boom des Levens) openbaar toegankelijk. Het eerste deel van het handschrift dat 34 bladen (68 pagina's) telt, is in een zeer net zeventiende-eeuws handschrift geschreven, wellicht dat van Grotius' broer Willem de Groot (1597-1662), ${ }^{14}$ op goede kwaliteit kanselarijpapier in folioformaat $(31,1$ $\times 20,8 \mathrm{~cm}$ ). Het kortere tweede deel is een negentiende-eeuws afschrift van een

14 Kromhout \& Offenberg (2019: 2) gaan ervan uit dat het handschrift door Grotius' secretaris is geschreven. 
resolutieconcept. Onlangs is door David Kromhout en Adri Offenberg een facsimile-uitgave van het eerste deel uitgegeven met een transcriptie, een moderne Nederlandse en Engelse vertaling en een inleidend commentaar.

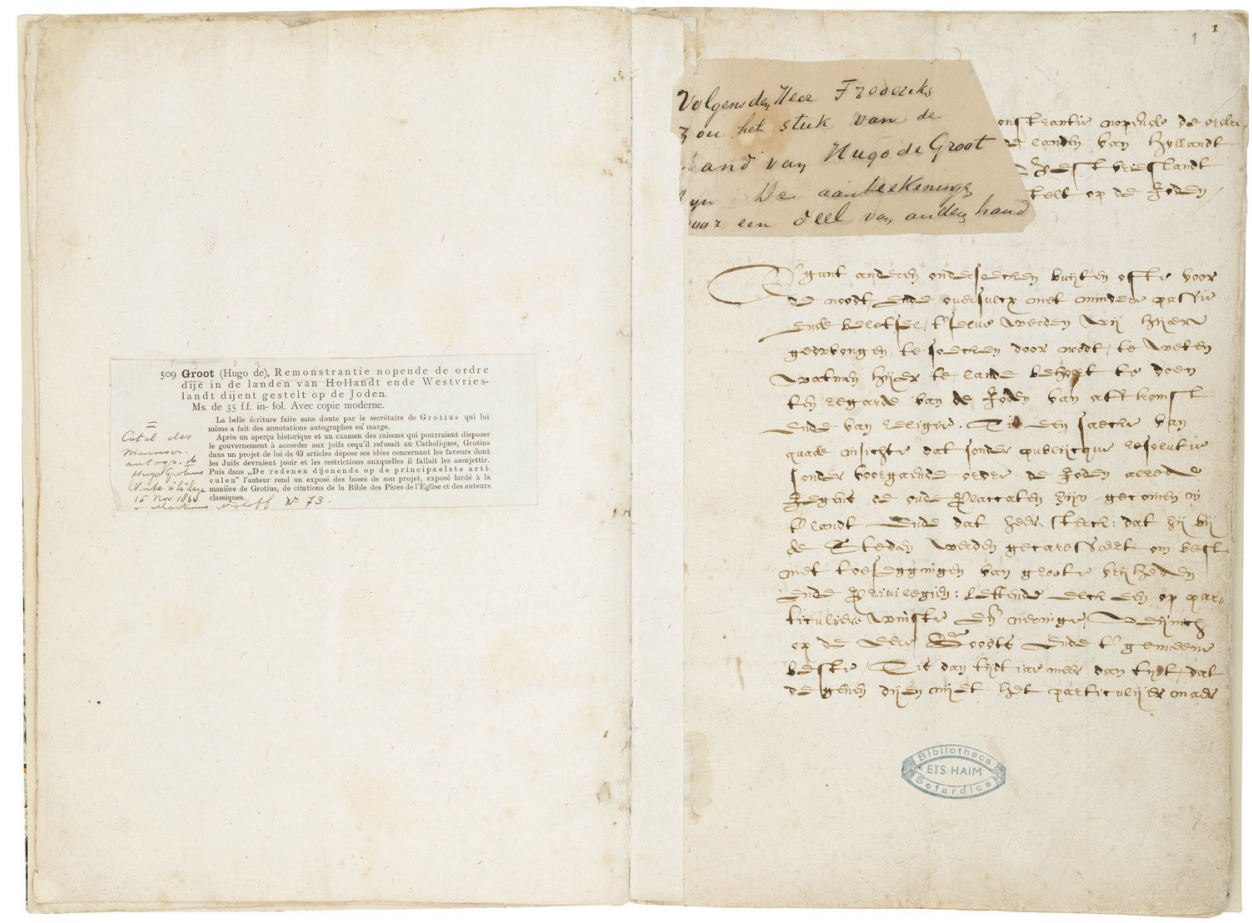

Afbeelding 5. Het handschrift van de Remonstrantie, fol. 1r; bron: Hugo de Groot, Remonstrantie, fol. 1. Handschrift Ets Haim. Ets Haim - Livraria Montezinos, Amsterdam, signatuur E 48 A 02

De Remonstrantie bestaat uit drie delen: 1) een inleiding; 2) 49 artikelen en 3 ) een verantwoording van de afzonderlijke artikelen. In de inleiding stelt Grotius in opdracht te handelen teneinde orde op zaken te stellen. ${ }^{15}$ Hoewel de 'oude plakkaten' dit verbieden, hebben vele steden inmiddels de joden omwille van gewin toegelaten. Hij wil daarom een reglement opstellen en antwoord geven op drie "principale questiën": 1) Of de joden moeten worden toegelaten; 2) indien dat het geval is, of zij dan de vrijheid moeten hebben hun religie uit te oefenen;

15 De Groot (1949: 70) benadrukt zelfs dat De Groot stelt gedwongen te zijn om het reglement op te stellen. Dat valt echter niet op te maken uit de door Meijer geciteerde zin "T'is een saecke van quade insichte, dat sonder publijcqe resolutie sonder voorgaende ordre de Joden alrede jegens de oude Placcaten zijn gecomen in t'landt ende dat zeer sterck: dat zij bij de Steden werden gecaresseert om best met toeseggingen van groote vrijheden ende Privilegien: lettende elck een op particuliere winste ende neringhe, weynich op de eere Goodts ende 't gemeene beste" (regel 7-17; hier geciteerd naar Kromhout \& Offenberg 2019: 59) en wordt dan ook niet door Kromhout \& Offenberg overgenomen. 
3) hoe de gevaren voor de christelijke religie en de staatspolitiek zoveel mogelijk kunnen worden beperkt.

Op de eerste pagina's herhaalt De Groot allerlei oude antisemitische beschuldigingen van de joden. De Talmoed, "der Joden tweeden bijbel" zou oproepen tot het systematisch mishandelen van christenen. Toen zij nog sterk waren, ten tijde van Trajanus, zouden zij 200.000 andersdenkenden hebben vermoord met o.a. uitingen van kannibalisme. Hij noemt allerlei beschuldigingen van kindermoord uit de middeleeuwen. Vanwege dit soort wandaden zijn zij in grote delen van Europa, ook uit de Nederlanden verbannen. Dat zij nu, in Grotius' tijd dit soort zaken niet meer doen, komt omdat ze er de macht niet voor hebben. Dit zouden dus goede argumenten zijn, zegt De Groot, om joden niet toe te laten. In hoeverre De Groot zelf echt in deze beschuldigingen heeft geloofd, is de vraag. In de Remonstrantie merkt hij in regel 377-379 op dat veel van de feiten die de joden worden aangewreven niet juridisch zijn onderzocht. Voorts meldt hij jodenvervolgingen "sonder forme van Justitie" vanwege de hebzucht van vorsten. Wat hijzelf werkelijk dacht, zou hij een paar jaar later in zijn Bewys van den waren Godsdienst en de Latijnse vertaling ervan De veritate religionis christianae tonen. Hier komen we nog op terug.

Hij ziet echter betere argumenten om de joden wel toe te laten. De Groot komt tot vijf conclusies: 1) de apostel Paulus zegt uitdrukkelijk dat uiteindelijk de bekering van het joodse volk te verwachten valt. Om die reden is het nodig dat joden kunnen leven temidden van echte christenen die zich van de beeldendienst hebben afgewend; 2) zij hebben kennis van het Hebreeuws, de taal van de Heilige Schrift in het Oude Testament; 3) de standvastigheid van de joden is een levend voorbeeld voor de christenen; 4) het ongeloof van de joden contrasteert met dat van de christenen die dankbaar kunnen zijn dat zij uitverkoren zijn en 5) er zijn in Nederland veel verschillende godsdiensten en de meest afwijkende is het minst gevaarlijk.

Na deze inleiding die de eerste 531 regels $^{16}$ op de eerste 11 folia beslaat, komt De Groot tot zijn eigenlijke reglement dat 49 artikelen telt en ruim 300 regels telt van regel $532 \mathrm{op}$ fol. 11v tot regel $835 \mathrm{op}$ fol. 21r. Van deze artikelen zijn de volgende vanuit het oogpunt van de toenmalige internationale praktijk het opmerkelijkste:

- Loyaliteit. (artikel 1-3) Joden moeten binnen acht dagen na aankomst een eed van trouw aan de staat afleggen en tevens aantonen gelovig te zijn.

- Vestiging. (artikel 5-6) Joden mogen zich tot een aantal van tweehonderd families (in Amsterdam driehonderd) overal vrij vestigen.

- Omgang met christenen. (artikel 6) Joden mogen vrij ondernemen, want dat is goed voor de economie. (artikel 25, 27-31) Ze mogen vrij met christe-

${ }^{16}$ Hier is de regeltelling in de editie Kromhout \& Offenberg (2019: 59-197) aangehouden. 
nen omgaan, maar mogen niet met christenen trouwen, hen niet bekeren, geen christelijke bedienden hebben en ook niet voor christenen werken, uitgezonderd vroedvrouwen en minnen. (artikel 33) Een christen die zich tot het jodendom bekeert, wordt verbannen.

- Religie. (artikel 7) Joden mogen hun religie vrij belijden, (artikel 17) de Hollandse overheden mogen van hen geen getuigenis vergen op de sabbat of joodse feestdagen. (artikel 26) Omgekeerd mogen joden niet werken op zondag. (artikel 20) Een door de joodse gemeenschap geëxcommuniceerde Jood mag een beroep doen op de plaatselijke overheid.

- Status. (artikel 39-42) Joden hebben alle rechten en plichten als andere burgers en mogen alle beroepen bekleden, behalve officiële staatsambten en militaire functies. (artikel 24) Een speciaal jodenteken mag niet verlangd worden.

- Huwelijk. (artikel 45-46) Huwelijken en scheidingen moeten voor de magistraat worden geregistreerd.

\section{De verantwoording}

In het derde deel, regel 848 (fol. $21 \mathrm{v}$ ) tot 1406 (fol. $35 \mathrm{v})^{17}$ geeft Grotius in ruim 550 regels een verantwoording van zijn afzonderlijke artikelen, zoals hij ook in zijn overige werken zijn argumentatie met citaten pleegt te onderbouwen.

Uit met name Grotius' verantwoording van de afzonderlijke punten blijkt dat hij bekend was met voorgaande keuren van Alkmaar (1604), Haarlem (1605) en natuurlijk van zijn eigen stad Rotterdam (1610). De verhoudingsgewijs grote aandacht die in artikelen 12-15, 25, 27-29 en 33-38 wordt besteed aan "blasfemie" van joodse zijde jegens het christendom, bekering van christenen tot het jodendom en gemengde huwelijken of contacten is duidelijk ingegeven door het Hoornse proces van 1614 dat de aanleiding was tot het opstellen van het reglement. ${ }^{18}$

De Groot verwijst vooral naar de Corpus Juris Civilis en andere Romeinse wetgeving. Ten eerste was deze destijds een belangrijk referentiepunt voor contemporaine wetgeving (Kromhout \& Offenberg 2019: 38) en ten tweede zag De Groot deze kennelijk als een neutrale bron die door niemand kon worden betwijfeld. Bovendien trachtte hij zo te vermijden dat er voor de joden uitzonderingen

17 Op fol. 26r is de paginering per ongeluk overgeslagen, waardoor de navolgende pagina's steeds een met één te laag nummer hebben. De laatste pagina fol. $35 \mathrm{v}$ is in de oorspronkelijke telling dus $34 \mathrm{v}$.

18 Van der Haven (2018: 199-200) concludeert o.a. op basis van deze artikelen dat juist de remonstranten de joden wilden vervolgen en de contraremonstranten hen tolereerden. Dit is echter in tegenspraak met dat de keuren van (toen) grotendeels remonstrantse steden als Alkmaar, Haarlem en met name Rotterdam expliciet tolerant tegenover de joden stonden. Ons inziens moet inzake De Groot (1949: 20-32) gevolgd worden die zijn mening met verwijzingen naar calvinistische theologische autoriteiten onderbouwt. 
werden gemaakt waarop zich dan later bijv. katholieken als op jurisprudentie konden beroepen. Daarom was De Groot niet voor het geven van toestemming om nieuwe synagogen te bouwen (Kromhout \& Offenberg 2019: 40-43).

Een andere reden, die door Joke Spaans (2004: 79) wordt genoemd, is dat de Romeinse wetgeving een duidelijke standaard zette voor het omgaan met religies die afweken van de staatsreligie. Op strikt religieus terrein mochten ze autonoom zijn, zolang als ze geen pogingen deden om tot een hogere graad van organisatie over te gaan. Het bleven collegia illicita die hoogstens gedoogd werden. Dat komt overeen met de nadruk die Grotius in zijn reglement (artikel 39) legt op het feit dat joden gelijk moeten zijn voor de wet. In zijn commentaar licht hij dit toe: "De gemeenschap vande Joden bestaet purelijck in de religie ende nijet daerbuijten" om vervolgens uit te leggen, waarom zij (buiten de strikt religieuze) geen eigen instellingen mogen hebben.

\section{8 . Het resultaat}

Het is duidelijk dat de Staten opzettelijk aan twee personen die elkaars ideologische tegenpolen waren om advies hebben gevraagd (Blom e.a. 1995: 81). Waarom Pauw de opdracht kreeg, is duidelijk: Amsterdam had verreweg de grootste groep joden binnen haar muren en uit Amsterdam kwamen ook de felste protesten tegen joodse aanwezigheid van de kant van de gereformeerde kerkenraad. De reden om de nog vrij jonge raadspensionaris van Rotterdam eveneens een ontwerp te belasten, is minder duidelijk. Het voor de joden meest goedgunstige ontwerp was op dat moment de hierboven genoemde keur van Haarlem (De Groot 1949: 38-41; Kromhout \& Offenberg 2019: 16-19). Wat vanuit het gezichtspunt van de Staten voor De Groot moet hebben gesproken is dat hij zich in zijn Ordinum Pietas expliciet voor zeggenschap van het landsbestuur in religieuze zaken had uitgesproken, een lijn die De Groot overigens met zijn nadruk op de Romeinse wetgeving in de Remonstrantie eveneens volgde. Bovendien was hij als advocaat-fiscaal hun 'eigen man'.

Voordat de Staten zich hadden kunnen uitspreken, nam Amsterdam op 8 november 1616 op eigen houtje een voorlopige jodenkeur aan, waarin werd bepaald dat de joden de christelijke godsdienst niet mochten belasteren en dat elk vleselijk contact van joden met christelijke vrouwen, uitdrukkelijk ook met hoeren, verboden is. De bepaling was

by provisie tot dat by Resolutie van de Ed $<$ ele $>$ Gr $<$ oot $>-$ Mo $<$ gende $>$ Heeren Staten van Holland ende West-Vrieslandt ofte by mijne Heeren van den Gerechte hier op nader ende speciaelder ordre sal wesen geraemt. ${ }^{19}$

19 Noordkerk (1748: 470-495) behandelt achtereenvolgens allerlei bepalingen aangaande de opstelling van de stad jegens de joden (als laatste in een hele afdeling gewijd aan de omgang met 'anders- 
Vanwege de twisten tussen contraremonstranten en remonstranten zou een dergelijke keur nimmer worden uitgevaardigd. In de jaren 1616-1618 raakten de gemoederen steeds verder verhit, waarbij elke poging van de kant van de Staten om te sussen eerder voor nog fellere reacties zorgde van contraremonstrantse kant, waar men absoluut niet van enige overheidsbemoeienis in kerkelijke zaken gediend was. Na de arrestatie van De Groot in 1618 was het ondenkbaar geworden om een ontwerp van zijn hand aan te nemen. Daarom namen de Staten van Holland pas op 13 december 1619 een neutrale beslissing: de steden en landstreken mochten zelf weten, hoe ze met joden wilden omgaan, wel met de restrictie dat er geen aparte kleding of speciale tekens mochten worden vereist en dat joden niet vervolgd mochten worden (Blom e.a. 1995: 81-82). ${ }^{20}$

\section{Grotius' mening}

Wat dacht Grotius zelf eigenlijk over de joden? In de staatsgevangenis Loevestein schreef hij het werk dat in zijn tijd nóg bekender was dan De iure belli ac pacis, het traktaat Bewys van den waren godsdienst. Hierin trachtte hij op rationele gronden aan te tonen dat het christendom de juiste religie is. Het in verzen gestelde werkje was bedoeld ter ondersteuning van zeelui die in andere werelddelen in aanraking zouden komen met niet-christenen. Na zijn memorabele ontsnapping gaf De Groot het werkje in 1622 uit en werkte het ook om in een geleerd Latijns prozatraktaat De veritate religionis Christianae dat in zijn tijd en de navolgende eeuw in vele talen vertaald en vaak herdrukt werd.

Dit traktaat was in zes boeken ingedeeld. De eerste drie gaan over de christelijke religie en de andere drie gaan in debat met de destijds meest verspreide religies: heidendom, jodendom en islam. Afwijkend van de strenge calvinisten stelt Grotius zich relatief tolerant op jegens de joden. Waar hij in zijn Remonstrantie eerst allerlei antisemitische laster min of meer als 'feiten' vermeldt om vervolgens voorzichtig wat positiever te worden, gaat hij in zijn Bewys dat niet in opdracht geschreven was, heel anders tewerk. Hij spreekt hen in de proloog aan als "het volk van Abraham", de "bewakers van de Schrift", de nakomelingen van de heiligen en bloedverwanten van Jezus. Expliciet vermeldt Grotius, zowel in de Nederlandse tekst (Bewys 5, vers 659-664) als in de Latijnse (De veritate $5, \S 16$ ) dat de joden nimmer tot afgoderij zijn vervallen, zoals in een ver verleden vóór Mozes, zich niet bevlekken met rituele moorden en evenmin aan overspeligheid doen:

denkenden'). Noordkerk (1748:472) geeft daarbij ook een uittreksel uit de resolutie van 1616. Van der Haven (2018: 194) vermoedt dat deze bepalingen op basis van het verloren gegane resolutieconcept van Pauw zijn gebaseerd, welke aanname waarschijnlijk juist is. Verg. Blom e.a. (1995: 81-82).

20 Tekst van de resolutie afgedrukt bij Kromhout \& Offenberg (2019: 22, noot 39). 
Hoe komt dat God u nu soo deerelyk verlaet,

Daer gy tot Bahalim of Mologh niet en gaet,

Maer uwen God bid aen en hem met droeve klaghten,

Met vasten en gesught soekt 't uwaerts te versaghten,

Daer gy nogh bloed en stort, nogh breekt uws naestes bed.

Maer doorgaens wel beleeft de uyterlyke wet?

De enige joodse 'moord' die in zijn ogen overeind blijft staan, is die op Jezus, die Grotius vooral aan de verblinde priesterkaste toeschrijft. Anderzijds wijst hij erop dat in Jesaja 53 voorspeld is dat de Messias door de hand van zijn eigen volk moest sterven. De joden waren dus uiteindelijk een werktuig in Gods handen, al is hun verstrooiing en lijden na de verwoesting van de Tempel aan deze wandaad te wijten (De veritate $5, \S \S 19-20$ ).

Het vijfde boek 'tegen de joden' in Bewys en De veritate betreft verder vooral weerlegging van joodse argumenten tegen het christendom, waarbij zijn argumentatie die van een jurist is: eerst vermeldt hij een belangrijk argument van de tegenpartij en ontkracht dit vervolgens stap voor stap zoveel mogelijk op basis van logische argumenten en historische feiten. ${ }^{21}$ In zijn polemiek met het jodendom gebruikt hij twee hoofdargumenten: de wonderen van Jezus zouden beter bewijsbaar zijn geweest dan die van Mozes en andere joodse profeten. Jezus bracht slechts de vervulling van de wet van Mozes en mocht de voorgestelde veranderingen als Zoon van God doorvoeren. Hij kwam als Messias op de tijd en wijze die voorspeld waren in het Oude Testament. Verder zijn christenen geen polytheïsten, want de christelijke verering van Jezus als Gods Zoon komt voort uit de voorspellingen in het Oude Testament. Het boek eindigt met een gebed voor de joden dat God hen spoedig mag bekeren en vergeven.

Ook in zijn grote commentaren op het Oude en Nieuwe Testament, de Annotationes in Vetus Testamentum (1644) en Annotationes in Novum Testamentum (1641-1650) toont Grotius een relatief goede kennis van de joodse religie. Toen hij deze commentaren opstelde, correspondeerde hij over detailkwesties met Menasseh ben Israel (1604-1657), rabbijn en joods drukker in Amsterdam en een van de belangrijkste joodse denkers van zijn tijd.

\section{Conclusie}

In het algemeen kan worden gezegd dat Grotius tegenover de joden een voor zijn tijd tamelijk tolerant standpunt innam. Het ontwerp voor het Jodenreglement was een stuk dat hij in opdracht had geschreven. ${ }^{22}$ Hij heeft er dan ook geen Latijnse

${ }^{21}$ Zie meer in detail Heering (2004: 64-92) en Engelbrechtová (2014: 86-101), waarvan in deze paragraaf is uitgegaan.

22 Kromhout \& Offenberg (2019: 36-39) werpen de vraag op of De Groot niet van plan was om zijn Remonstrantie uit te geven, waarbij zij de aanwezigheid van het derde deel (commentaar) 
versie van gemaakt, zoals hij dat wel deed met geschriften die hem nader aan het hart lagen. In hoeverre hij werkelijk geloofde dat de door hem geciteerde beschuldigingen aan joods adres van rituele moorden juist waren, laat hij hier in het midden. Enerzijds stelt hij dat er wel erg veel van dit soort berichten zijn, maar anderzijds ontbreekt duidelijk juridisch onderzoek. Uit zijn Bewys en De veritate blijkt dat hij zelf kennelijk niet aan deze antisemitische laster geloofde.

Uit zijn latere werken waarin hij zich veel intensiever met religieuze problematiek bezig hield, blijkt oprechte interesse voor de problemen van het jodendom, erkenning van de rol die de joden voor het christendom hebben gespeeld en een poging om de relaties met de joden te regelen op een voor die tijd tolerante wijze.

\section{Bibliografie}

Bakhuizen van den Brink, Johan N. (1960): Documenta reformatoria. Teksten uit de geschiedenis van kerk en theologie in de Nederlanden sedert de Hervorming. Kampen: J.H. Kok.

Blom, Johan C. e.a. (1995): Geschiedenis van de joden in Nederland. Amsterdam: Balans.

Cohen, Job (2004): Toespraak door burgemeester Job Cohen bij de opening van de vernieuwde opstelling in de Grote Synagoge van het Joods Historisch Museum. Joods Historisch Museum, D010368. Getypt document.

Coster, Abraham (1609): Historie der Joden, die tzedert der verstooringe Ierusalems in alle landen verstroyt zijn. Amsterdam: Jan van Waesberghe.

Droogendijk, J.M. (1930): “Een vergeten kerkhof”. Rotterdamsch Jaarboekje 3, $62-88$.

Engelbrechtová, Jana (2014): O pravdě křest’anského náboženství. Olomouc: Univerzita Palackého. Groot, Hugo de (1844): Hugo de Groot's Bewijs van de Ware Godsdienst met zijne overige Nederduitsche Gedichten uitgegeven, Jeronimo de Vries (red.). Amsterdam: R. Stemvers.

Groot, Hugo de [1615]: Remonstrantie nopende de ordre dije/ in de landen van Hollandt/ ende Westvrieslandt/dijent gestelt op de Joden. Manuscript in 2 delen, $31,1 \times 20,8 \mathrm{~cm}$. Bibliotheek Ets Haim (Livraria Montezinos), signatuur EH 48 A 02, laatst geraadpleegd op 7.03.2019<http:// etshaimmanuscripts.nl/eh_48_a_02/>. Het gehele handschrift is nu in facsimile toegankelijk in Kromhout \& Offenberg (2019: $57-198)$.

Groot, Hugo de (1949): Remonstrantie nopende de Ordre dije in de Landen van Hollandt ende Westvrieslandt dijent gestelt op de Joden, Jaap Meijer (red.). Amsterdam: J. Meijer.

Grotius, Hugo (1831): De veritate religionis Christianae, Theod. Bergman (red.). Lugduni Batavorum (Leiden): C.G. Menzel \& J.C. Cyfveer.

Heering, J.P. (2004): Hugo Grotius as Apologist for the Christian Religion. A Study of his Work De veritate religionis christianae (1640). Leiden: Brill.

Israel, Jonathan I. (1995): The Dutch Republic. Its Rise, Greatness, and Fall 1477-1806. Oxford. Oxford University Press.

Israel, Jonathan I. (1997): "The intellectual debate about toleration in the Dutch Republic". In: Christiane Berkvens-Stevelink \& G.H.M. Posthumus Meyes (red.), The Emergence of Tolerance in the Dutch Republic. Leiden e.a.: Brill, 3-36.

als argument aangeven dat hij het wellicht van plan was. Op hun opmerking dat de tekst in het Nederlands was geschreven (Kromhout \& Offenberg 2019: 38) kan worden opgemerkt dat De Groot heel vaak van werken die hij van belang achtte versies in beide talen, het Nederlands en het Latijn makte. Er is geen Latijnse versie van het reglement bekend. 
Koeman, C. (1985): “Jan Huygen van Linschoten”. Revista da Universidade de Coimbra 30, 27-47. Kromhout, David, \& Adri K. Offenberg (2019): Hugo Grotius's Remonstrantie of 1615. Facsimile, Transliteration, Modern Translations and Analysis. Leiden/Boston: Brill.

Lewis, Charlton T., \& Charles Short (1958): A Latin Dictionary. Oxford: Clarendon Press.

Locke, John (1689): A Letter Concerning Toleration. Vertaling William Popple. London: Awnsham Churchill.

Michman, Jozeph (red.) (1984): Dutch Jewish History. Proceedings of the Symposium on the History of the Jews in the Netherlands. November 28-December 3, 1982, Tel Aviv-Jerusalem. Deel I. Assen/Maastricht: Van Gorcum.

Michman, Jozeph (red.) (1989): Dutch Jewish History. Proceedings of the Fourth Symposium on the History of the Jews in the Netherlands. 7-10 December, Tel Aviv-Jerusalem, 1986. Deel II. Assen/Maastricht: Van Gorcum.

Nellen, Henk (2007): Hugo de Groot. Een leven in strijd om de vrede, 1583-1645. Amsterdam: Balans.

Noordkerk, Hermanus (red.) (1748): Handvesten, ofte privilegien ende octroyen, mitsgaders willekeuren, costuimen, ordonnantien en handelingen der stad Amstelredam. Stuk 2. Amsterdam: Hendrik van Waesberghe \& Salomon en Petrus Schouten.

Poelhekke, J.J. (1978): Frederik Hendrik, prins van Oranje. Een biografisch drieluik. Zutphen: Walburg Pers.

Prins, Izak (1927): De vestiging der Marranen in Noord-Nederland. Amsterdam: Menno Hertzberger.

Ruusbroec, Jan van (2014): The Complete Ruusbroec, G. de Baare \& T. Mertens (red.). Turnhout: Brepols.

Spaans, Joke (2004): "Religious policies in the seventeenth-century Dutch Republic". In: R. Po-Chia Hsia \& Henk van Nierop (red.), Calvinism and Religious Toleration in the Dutch Golden Age. Cambridge: Cambridge University Press, 72-86.

Van der Haven, Alexander (2018): "Predestination and toleration: The Dutch Republic's single judicial persecution of Jews in theological context". Renaissance Quarterly 71, 165-205.

Van Eijnatten, Joris, \& Fred van Lieburg (2006): Nederlandse Religiegeschiedenis. Hilversum: Verloren.

Van Sevilla, Isidorus (1998): Sententiae, Pierre Caiyer (red.). Turnhout: Brepols.

Zwarts, Jac. 1928: "De eerste rabbijnen en synagogen van Amsterdam naar archivalische bronnen". Bijdragen en Mededeelingen van het Genootschap voor de Joodsche Wetenschap in Nederland, gevestigd te Amsterdam 4, 147-271. 